\title{
Effect of ethane 1,2-dimethane sulphonate on the cyclic AMP response in rat testis to stimulation by $\mathrm{HCG}$
}

\author{
Denise E. Bu'Lock and Pamela Jones \\ Unit of Reproductive Pharmacology, Department of Pharmacology, University of Manchester, \\ Manchester M13 9PT, U.K.
}

Ethane 1,2-dimethane sulphonate (EDS: $\mathrm{MeSO}_{2} \cdot \mathrm{OC}_{2} \mathrm{H}_{4} \mathrm{O} . \mathrm{SO}_{2} \mathrm{Me}$ ) is a non-steroidal antifertility agent (Cooper \& Jackson, 1970). In the rat a single i.p. dose of $75 \mathrm{mg} / \mathrm{kg}$ inhibits the production of testosterone by the testis (Bu'Lock \& Jackson, 1971/72), the effect being maximal by 7 days after injection and completely overcome in 6-9 weeks (Bu'Lock \& Jackson, 1975). While testicular steroidogenesis is depressed, serum and pituitary levels of LH are raised (Morris \& Jackson, 1975), suggesting that failure of the testis to produce testosterone is accompanied by, if not actually due to, inability to respond to $\mathrm{LH}$ in the normal manner by increasing testosterone formation.

Small quantities of $\mathrm{LH}$ or HCG $(<1 \mathrm{ng})$ stimulate the production and release of cyclic adenosine $3^{\prime}, 5^{\prime}$-monophosphate (cAMP) and of testosterone by the testis in vitro (Catt, Watanabe \& Dufau, 1972; Cooke, van Beurden, Rommerts \& van der Molen, 1972). In the present paper, we investigated the effect of EDS treatment on cAMP release by testicular tissue in response to added HCG, using the method described by Dufau, Watanabe \& Catt (1973), who showed that release of cAMP into the incubation medium is much greater than the increase in tissue cAMP levels.

Male American Wistar rats (350-400 g) were killed by decapitation from 4 to $96 \mathrm{hr}$ after administration of a single i.p. injection of EDS $(75 \mathrm{mg} / \mathrm{kg}$ ), made up in dimethyl sulphoxide (DMSO: Hopkin \& Williams, Romford, England): water $(1: 3 \mathrm{v} / \mathrm{v})$ or suspended in tricaprylin (trioctanoin: Fluorochem, Dinting Vale, Derbyshire, England). Control animals received 0.7-0.8 ml vehicle alone. The incubation procedure was similar to that of Dufau $e$ al. (1973). Testes were removed, weighed, decapsulated and preincubated for $1 \mathrm{hr}$ in $1.4 \mathrm{ml}$ Krebs-Ringer-bicarbonate (KRB) buffer, containing $1 \mathrm{mg}$ glucose $/ \mathrm{ml}$. After addition of 1 i.u. HCG (Sigma; or Pregnyl: Organon) in 0.1 ml phosphatebuffered saline, containing $1 \mathrm{mg}$ bovine serum albumin/ml and $0.5 \mathrm{ml} 20 \mathrm{~mm}$-theophylline (in KRB) incubations were continued for a further $2 \mathrm{hr}$. All incubations were at $33^{\circ} \mathrm{C}$ in $95 \% \mathrm{O}_{2}: 5 \% \mathrm{CO}_{2}$ with shaking. After $2 \mathrm{hr}$, cAMP was measured in samples $(25-100 \mu \mathrm{l})$ of the incubation medium by the radioisotope dilution assay with adenosine- $3^{\prime}, 5^{\prime}$ monophosphate binding protein (Gilman, 1970), using kits supplied by Boehringer-Mannheim (Cat. No. 15290). Satisfactory removal of interfering materials from the incubation samples was achieved by precipitation with ethanol ( 4 vols); after centrifugation the supernatant, combined with one ethanol washing, was freeze-dried and stored at $-20^{\circ} \mathrm{C}$ until assayed.

The results are shown in Table 1. The values for un-injected animals $(0 \mathrm{hr})$ are comparable with those reported by Dufau et al. (1973), i.e. 0-10 and 400-500 pmol cAMP/testis before and after stimulation by HCG. Some difficulty was encountered in obtaining satisfactory vehicle-only controls. Testes from rats injected i.p. with aqueous DMSO 12 or $24 \mathrm{hr}$ previously gave very variable values for basal and stimulated cAMP release, although by $48 \mathrm{hr}$ a normal picture was again obtained. DMSO has been the usual injection vehicle for EDS (Cooper \& Jackson, 1970) and it was employed in the present study for the 48 and $96 \mathrm{hr}$ data since these control values were satisfactory. Tricaprylin was used as the vehicle for the shorter time periods; basal and HCG-stimulated cAMP release were within the normal range of 4 and $24 \mathrm{hr}$ after injection, and below normal, but reproducibly so, after $12 \mathrm{hr}$. The results were expressed as pmol/testis rather than as $\mathrm{pmol} / \mathrm{g}$ wet weight of tissue, since the various treatments produced slight changes in testicular weight (Table 1).

Despite the admitted imperfection of this procedure, the results in Table 1 clearly demonstrate that within $48 \mathrm{hr}$ of EDS injection in vivo the capacity of testicular tissue to release cAMP when stimulated by HCG was almost abolished. The trend was also apparent at $4 \mathrm{hr}$ after EDS treatment. 
Table 1. Effects of ethane 1,2-dimethane sulphonate (EDS) in vivo on the release of cAMP (pmol/testis) from rat testicular tissue stimulated by HCG in vitro

\begin{tabular}{|c|c|c|c|c|c|c|}
\hline & \multicolumn{6}{|c|}{ Period of EDS stimulation in vivo (hr) } \\
\hline & 0 & 4 & 12 & 24 & 48 & 96 \\
\hline Vehicle & 0 (control) & Tricaprylin & Tricaprylin & Tricaprylin & DMSO & DMSO \\
\hline $\begin{array}{l}\text { Testicular weight }(\mathrm{g}) \\
\text { Vehicle only } \\
\text { Vehicle + EDS }\end{array}$ & $1.80 \pm 0.04$ & $\begin{array}{l}1.85 \pm 0.11 \\
1.84 \pm 0.06\end{array}$ & $\begin{array}{l}1.72 \pm 0.03 \\
1.65 \pm 0.03^{* *}\end{array}$ & $\begin{array}{l}1.87 \pm 0.09 \\
1.87 \pm 0.05\end{array}$ & $\begin{array}{l}1 \cdot 78 \pm 0.08 \\
2 \cdot 00 \pm 0.12\end{array}$ & $\begin{array}{l}1.86 \pm 0.03 \\
1.86 \pm 0.03\end{array}$ \\
\hline $\begin{array}{l}\text { Release of cAMP } \\
\text { Vehicle only } \\
\text { Vehicle + HCG } \\
\text { Vehicle + HCG + EDS }\end{array}$ & $\begin{array}{c}10 \\
520 \pm 80\end{array}$ & $\begin{array}{c}10 \\
560 \pm 90 \\
310 \pm 150\end{array}$ & $\begin{array}{c}10 \\
260 \pm 10 \\
74 \pm 10\end{array}$ & $\begin{array}{c}10 \\
415 \pm 130 \\
150 \pm 50\end{array}$ & $\begin{array}{c}10 \\
290 \pm 140 \\
14 \pm 10\end{array}$ & $\begin{array}{c}10 \\
460 \pm 90 \\
24 \pm 20\end{array}$ \\
\hline $\begin{array}{l}\text { Effect of drug } \\
\quad \%(H C G+\text { vehicle })\end{array}$ & & 56 & $28 * * *$ & $36 * *$ & $2^{* *}$ & $4^{* *}$ \\
\hline
\end{tabular}

Values are means \pm S.E.M. from a minimum of 5 experiments.

Significantly different from controls, ${ }^{* *} P<0.01$; $^{* * *} P<0.001$ (unpaired $t$ test).

The fall in HCG response occurs much earlier than the decline in steroidogenesis following a similar dose of EDS; testosterone formation has fallen to only half its normal rate by $60 \mathrm{hr}$ after EDS injection (Bu'Lock \& Jackson, 1975). If these two processes are related, their differing rates may, at least in part, be due to the time required for the existing enzymes of steroid transformation to decay. They could also reflect the fact that the particular $\mathrm{LH}$ receptor sites controlling steroidogenesis have a much higher affinity for the hormone than do most of the sites which respond by producing cAMP (Moyle \& Ramachandran, 1973).

Correlation of our observations with the effects of EDS in the intact animal is difficult, since although the HCG-stimulated release of cAMP from the interstitial tissue is a well-established phenomenon, cAMP is normally thought of as an intracellular mediator. Nevertheless, our results show that EDS interferes with the ability of testicular tissue to respond to LH, normally one of the most important stimulators of the testis, because of the failure to produce the cAMP mediator. The effect might be due to an interaction of EDS with the receptor sites of the interstitial cells, or to changes in the properties of the Leydig cell membrane similar to those following hypophysectomy, which also leads to loss of HCG-binding capacity (Catt, Tsuruhara, Mendelson, Ketelflegers \& Dufau, 1974).

This work was supported by grants from the Ford Foundation and the Medical Research Council under the direction of Dr H. Jackson who also supplied the EDS. We thank Professor H. Schnieden for departmental facilities and encouragement.

\section{References}

Bu'Lock, D.E. \& JACkson, C.M. (1971/72) Suppression of testicular androgen synthesis in the rat by ethylene dimethane sulphonate. Gynecol. Invest. 2, 305-308.

Bu'Lock, D.E. \& JACKson, C.M. (1975) Suppression of androgen synthesis in the rat by ethane 1,2-dimethane sulphonate. J. Steroid Biochem. 6, 1181-1185.

Catt, K.J., Watanabe, K. \& DUfaU, M.L. (1972) cAMP release by rat testis during gonadotrophin stimulation in vitro. Nature, Lond. 239, 280-281.

Catt, K.J., Tsuruhara, T., Mendelson, C., KetelFlegers, J.M. \& DUfaU, M.L. (1974) Hormone binding and target cell activation in the testis. In Current Topics in Molecular Endocrinology, vol. 1, pp. 1-30. Eds M.L. Dufau, \& A.R. Means. Plenum Press, New York.

CoOke, B.A., van Beurden, W.M.O., Rommerts, F.G. \& VAN DER MOLEN, H.J. (1972) Effect of trophic hormones on $3^{\prime} 5^{\prime}$-cyclic AMP levels in rat testis interstitial tissue and seminiferous tubules. $F E B S$ Letters 25, 83-86.

COOPER, E.R.A. \& JACKson, H. (1970) Comparative effects of methylene, ethylene, and propylene dimethanesulphonates on the male rat reproductive system. J. Reprod. Fert. 23, 103-108.

Dufau, M.L., Watanabe, K. \& CatT, K.J. (1973) Stimulation of cyclic AMP production by rat testis 
during incubation with HCG in vitro. Endocrinology 92, 6-11.

GilmaN, A.G. (1970) A protein binding assay for adenosine 3',5' cyclic monophosphate. Proc. natn. Acad. Sci. U.S.A. 67, 305-312.

MorRIs, I.D. \& JACKSON, C.M. (1975) Serum and pituitary gonadotrophin levels following selective destruction of the interstitium by ethylene dimethanesulphonate in $\alpha$-chlorohydrin-sterilized male rats. J. Endocr. 67, 21-22P.

MOYLE, W.R. \& RAMACHANDRAN, J. (1973) Effect of LH on steroidogenesis and cyclic AMP accumulation in rat Leydig cell preparations and mouse tumor Leydig cells. Endocrinology 93, 127-134.

Received 2 December 1975 